\title{
Tensions between feminist principles and the demand for prostitution in the neoliberal age: A critical analysis of sex buyers' discourse
}

\author{
Tensiones entre los principios feministas \\ y la demanda de prostitución en la era neoliberal: \\ un análisis critico del discurso de los sujetos prostituyentes
}

ROSA M. SENENT JULIÁN (Dublin City University, Ireland)

Artículo recibido: 29 de noviembre de 2018

Solicitud de revisión: 4 de junio de 209

Artículo aceptado: 11 de julio de 2019

Senent Julián, Rosa Marina (2019). Tensions between feminist principles and the demand for prostitution in the neoliberal age: A critical analysis of sex buyer's discourse. Recerca. Revista de Pensament $i$ Análisi, 24(2), pp. 109-128.

\begin{abstract}
In the age of neoliberalism, feminists strongly disagree on the ideal legal status of prostitution while the pro-prostitution lobby endeavours to keep their male-dominated business running smoothly. Feminist debates should be concerned with the sex buyers' belief system about women, which is likely to have practical consequences in the way they behave with women (prostituted and non-prostituted) in terms of sexuality and, therefore, for feminist purposes of equality on a broader scale. A Critical Discourse Analysis of buyer-authored online reviews of prostituted women provides the opportunity to verify whether the relationship they establish with them is based on democratic mutual equality or gendered power relations driven by domination and subordination.
\end{abstract}

Key Words: Feminism, Neoliberalism, Prostitution, Masculinity, Critical Discourse Analysis.

\section{Resumen}

En la era del neoliberalismo, no hay consenso entre las feministas acerca del estatus legal que debería tener la prostitución; mientras, el lobby pro-prostitución intenta proteger tan lucrativo negocio. Los debates feministas deben abordar críticamente el sistema de creencias de los sujetos prostituyentes, en tanto que afecta a cómo actúan con las mujeres (prostituidas y no prostituidas) dentro del marco de la sexualidad y, por tanto, al potencial logro de la igualdad fáctica a nivel social. El análisis crítico del discurso online de los sujetos prostituyentes sobre las mujeres prostituidas permite comprobar si las relaciones que establecen con ellas están basadas en términos igualitarios o en la dicotomía dominación-subordinación característica de las relaciones de poder de género.

Palabras clave: feminismo, neoliberalismo, prostitución, masculinidad, análisis crítico del discurso. 


\section{INTRODUCTION}

After the fall of communism in the zoth century, the capitalist model, which feeds on the exploitation of the poor, the racially excluded and women, had become hegemonic in a world where the alliance between patriarchy and neoliberalism had already succeeded. Feminism, as the social and intellectual movement that fights for women's rights, possesses a historically unique political power. However, the ability of patriarchal neoliberalism to phagocytise the revolutionary potential of any given political counter-narrative is inexhaustible. This does not deny or automatically kill feminism's potential for change, but it should make feminists wary. Feminist critical thinking is necessary for the movement to stay effectively revolutionary without falling under neoliberal whims and purposes, which are intrinsically anti-feminist.

Different contexts provide diverse conditions that characterise the current diversity of feminism. Despite this, among feminists from different social and economic backgrounds, there is generally a consensus around certain issues: most would agree that women must have the right to vote, to study, to get divorced, etc. However, some issues have become utterly bi-polarised. Such is the case for prostitution. For centuries, the cultural order of patriarchy has conditioned numerous socialisation processes that configure our individual and collective identity (Salazar, 2012: 91). Prostitution forms part of the gender socialisation processes that configure and reinforce gendered power relations (Gimeno, 2018: 15).

In the age of capitalist hegemony, prostitution has thrived thanks to two coinciding factors that have developed a political fissure in feminism regarding prostitution: firstly, neoliberalism, which foments a deceiving concept of human freedom, decontextualised from social, political, economic and cultural factors that determine each individual's status within society. Secondly, the patriarchal backlash that tries to undermine feminist social advances (Gimeno, 2018; Cobo, 2017). This «coincidence» deserves further attention on the part of feminists. More than ever, a feminist analysis of prostitution needs to critically address both capitalist and patriarchal power relations.

In this article, current feminist debates on prostitution within the neoliberal context will be discussed. Following the contextualisation of the issue, a summarised analysis of online reviews written in www.PunterNet.com by sex buyers will be presented. ${ }^{1}$ This analysis, carried out by means of Critical Discourse Analysis (CDA), aimed at identifying the main tenets of the power-structures implied in discourse. Observing how sex buyers communicate among themselves revealed the assumptions that form a set of beliefs common to sex buyers about prostituted women and girls, and insight into their belief system about women in general. The article exposes a number of relevant issues that arise from the analysis of sex buyers' discourse that affect feminist purposes of equality at a larger scale.

1 For more information on the methodology, the selection of data and an extended analysis of the reviews see Senent (2017). 


\section{PROSTITUTION IN THE NEOLIBERAL AGE}

\subsection{Current feminist debates ${ }^{2}$}

In the 19th century, British feminists of the abolitionist movement under Josephine Butler's lead were united in holding men accountable for the abuse of women in prostitution (Barry, 1979). However, over the last few decades, the feminist movement has been divided between abolitionists, who believe prostitution is a form of violence against women and aspire to its eventual extinction by supporting a legal approach - known as Nordic model - that shall reduce the demand, and regulationists, who believe prostitution is only a job stigmatised because of moralist prejudices and aim at making it legal. Both anti and pro-prostitution feminists place a great deal of importance on violence suffered by prostituted women, proving that women's well-being is the major concern on both sides, but they differ on the explanations and solutions.

The anti-prostitution side is epitomised by organisations such as WHISPER (Women Hurt In Systems of Prostitution Engaged in Revolt), founded in the early 1980 os by Evelina Giobbe, an ex-prostituted woman who defines prostitution as commercial sexual violence. Nowadays, countless formerly prostituted women and feminist authors have made the link between prostitution and rape. Many organisations worldwide present prostitution as sexual violence and offer help and support to prostituted women. Some of them are Asociación para la Prevención, Reinserción y Atención a la Mujer Prostituida (APRAMP) in Spain (www.apramp.org), Ruhama in the Republic of Ireland (www.ruhama.ie) and Pink Cross Foundation Australia (www.pinkcross.org.au).

The pro-prostitution side is represented by COYOTE (Call off Your Old Tired Ethics), a San Francisco-based prostitutes' rights organisation founded by Margo St. James in 1973 advocating decriminalisation. They proposed to re-signify the word «whore» through the legal status of prostitution to end the stigma associated with «sex work». In 1989, Gail Peterson published the Vindication of the Rights of Whores, where she exposed the arguments of the pro-prostitution lobbies in the United States. Some current pro-prostitution groups are Hetaira in Spain (www.colectivohetaira.org), the English Collective of Prostitutes (www.prostitutescollective.net) and Asociación de Mujeres Meretrices de la Argentina (www.ammar.org.ar).

Julia O'Connell Davidson, whose large research on prostitution has involved ethnographic and interview work with prostitutes, third-party organisers of prostitution and sex buyers in both affluent and poor countries, explains that female prostitutes are legally and socially constructed as a separate class of persons. They are subjected to civil and human rights abuse in all countries where she conducted research. Therefore, she sympathises with sex-work feminists who demand specific protection for prostitutes so that their human rights are ensured. However, her data show such a gloomy picture as to what prostituted women must endure that she finds no reasons to justify the per-

Debates on prostitution throughout history have been and continue to be wide and complex. For practical reasons, I shall exclude religious and conservative-based discourses in favour of or against prostitution (such as the prohibitionist model) and focus solely on feminist debates. 
petuation of prostitution and, in this sense, she is in sympathy with the feminist abolitionist case (O'Connell Davidson, 2002: 84).

\section{PROBLEMATISING PROSTITUTION}

Women in prostitution have rights and deserve respect not because or despite the fact they work as prostitutes, but because they are human beings (O'Connell Davidson, 2002: 93), something both anti and pro-prostitution feminists would agree upon. In the light of these radically opposed viewpoints, an effort to subject ourselves to selfcriticism could lead us to a less bitter debate and the possibility of working together, at least to a certain extent. While the abolitionist movement had to accept that some women may want to engage in «sex work», pro-prostitution feminists must be aware that their approach to prostitution is rightly applied only to the experience of a small privileged minority of «First World» women, as survivors (Carter \& Giobbe, 2006) and academics (O'Connell Davidson, 2002) have noted.

Since women of colour and poor women are the most affected by prostitution, Vednita Carter and Evelina Giobbe (2006) have noted as the «most disturbing aspect of the international prostitutes' rights movement» the fact that a hierarchy has been built on race and class privilege to inform its ideology. According to them, sex-work feminists ignore the social context in which prostitution occurs - especially the race/class power differential existing between prostituted women and sex buyers - and argue that leading marginalised women to believe decriminalisation would change their lives within prostitution is «dangerous and irresponsible» (Carter \& Giobbe, 2006: 31-35). Sheila Jeffreys has pointed out that the position of a small number of prostitutes' rights activists has gained great publicity because it is popular with the media and the powerful economic and political forces that represent pimps and sex buyers. ${ }^{3}$ Meanwhile, organisations that represent prostituted and ex-prostituted women who find prostitution dangerous and damaging is not well-known.

The prostitution revenue worldwide is estimated to be $\$ 186$ billion; estimates for the United States alone, where the industry is predominantly illegal, exceeds $\$ 14$ billion annually. ${ }^{4}$ Economic growth is likely to follow legalisation (Jeffreys, 2008). Trafficking and sex tourism are lucrative businesses that increase in countries where prostitution is legalised or decriminalised (Cho et al., 2013). Despite neoliberal claims, this «worldwide multi-billion dollar business [...] cannot de-link itself from [sex] trafficking» because the purpose of trafficking in women is, precisely, to prostitute women (Bhattacharya, 2016: 84). Survivors have noted legalisation and decriminalisation to be «social experiments that have repeatedly failed».5

3 In 1981, COYOTE had 97\% syndicated activists advocating for decriminalisation. Only 3\% were prostituted women. However, the myth was fed that it was an organisation mostly formed by prostitutes. Such myth gave legitimacy to its claims (Jeffreys, 2008: 72).

4 Prostitution Revenue by Country. Global Black-Market Information. Havocscope. Retrieved from http://www.havocscope.com/prostitution-revenue-by-country/ [Consulted 26th August, 2018].

5 Even Gail Peterson gives proof of it in Vindication of the Rights of Whores (Carter \& Giobbe, 2006: 37). 
However, this «failure» is a plain success from a neoliberal point of view: in 1998 , the International Labour Organisation recommended governments to legalise prostitution to benefit from the revenues. Since then, Holland, Germany and New Zealand have done so (Ekman, 2013: 3). In Germany, as a consequence of the prostitution law, pimps are now «entrepreneurs»; sex trafficking increased dramatically, a process «euphemistically described as facilitated migration» (Raymond, 2003: 6). The terminology of the socalled «sex industry» has become business-like, providing the pro-prostitution lobby with a set of euphemisms aimed at disguising their interest on the legalisation/decriminalisation of the industry (Cobo, 2017: 114).

\subsection{The excuse of male sexuality}

Among the arguments and prejudices ${ }^{6}$ in defence of prostitution, there is the pervasive belief according to which prostitution is necessary and/or a social service of sorts. This is based on two fallacious assumptions that create the illusion that prostitution cannot be eliminated. Firstly —even though men rape non-prostituted women despite the existence of prostitution- essentialist accounts on human sexuality have endeavoured to justify that male sexuality is instinctual, uncontrollable, and that men need an outlet or else they will endanger the safety of all women. This prejudice is at the core of what has become known as rape culture. Secondly, women are artificially divided into two groups: respectable — good women, epitomising purity or motherhood and branded by marriage - and unrespectable — bad women, "public property» branded by prostitution - according to patriarchal standards of social respectability.

\subsection{A gendered phenomenon}

The huge quantity of women in prostitution and the comparatively small number of male prostitutes is the result of unequal social and economic conditions that cannot be overlooked. Importantly, the «customers» of both female and male prostitutes are mostly men. This shows that the model of masculinity that demands and perpetuates prostitution goes beyond sexual orientation and is potentially endorsed by any man (Ranea, 2017: 137). The implications and consequences are politically meaningful and affect women's lives worldwide in practical and symbolic terms. Currently, however, conservatives and neoliberals, along with many feminists and left-wing people, advocate for a gender-blind ideology according to which prostitution is aseptic in terms of gender.

This is «the universal argument» of the contractarian defence for which prostitution is a «trade fit for anyone to enter»; that the majority of prostitutes are women is, for contractarians, merely a «contingent fact» (Pateman, 1988: 192). As Ekman has highlighted, we are not supposed to speak about women and men, but about «sellers» and «customers». Indeed, «the story of the sex worker is above all a story of the wom- 
an» since, as if selling sex were unidirectional, at the centre of the picture «stands not the man who does the buying, but the woman who does the selling» (2013: 5). The «sex industry» regards buying as a privilege that must be protected: defending the «right» of women to be prostitutes means to implicitly defend men's right to demand prostitution.

\subsection{The myth of free choice}

The «myth» of free choice (de Miguel, 2015) is a complex one within the context of patriarchal, capitalist societies - where sexism, racism, and classism are rampant. The fact that women face really difficult situations of personal, social and/or economic vulnerability is not taken seriously enough by pro-prostitution proponents. Marxist authors, starting with Marx and Engels in 1848, already saw in prostitution a manifestation of capitalist and gendered power relations (Bhattacharya, 2016). In 1913, Lenin called it «trade in female flesh», asserting that prostitution will exist for as long as wage-slavery exists and that «slavery, feudalism and capitalism are identical» in that only the form of exploitation changes: the exploitation itself remains (1971: 230-231). In 1921, Aleksandra Kollontă1 (1977) called it «this sinister legacy of our bourgeois capitalist past» which «threatens the feeling of solidarity and comradeship between working men and women».

In origin, prostitution is not a capitalist phenomenon but a patriarchal one: it did not occur «when people began to buy and sell but is instead rooted in the relationship between men and women». However, when prostitution is incorporated into a highly developed market economy, this power struggle in itself becomes a commodity. Nowadays, we find ourselves «dealing with an ideology that tries to depict prostitution as freedom». The same institution that was traditionally defended by describing prostituted women as inferior ${ }^{7}$ is now defended by asserting the prostitutes' rights: the proprostitution lobby does its job by spreading a discourse on prostitution based on a neoliberal co-optation of left-wing ${ }^{8}$ and feminist terms. 9 This goes well «with the prevailing free-market ideology, a kind of liberalism for which "the equal value of all people" is axiomatic». To assert that there are people who are biologically inferior is alien to this ideology, but «it is equally taken for granted that the free market must be defended at all costs» and «it is the free market that reduces people to mere commodities» (Ekman, 2013: 88-91).

\footnotetext{
Old defences of prostitution reproduced sexist prejudices and, claiming that prostitutes had poor bodily and mental constitution, took this to be the cause for them to end up there (see, for example, Kemp, 1936).

8 Paradoxically, legalisation is a legal model characteristic of right-wing governments. For example, under Franco's dictatorial regime, prostitution was legalised in Spain: it «provided jobs for poor women and solace for men who were struggling in postwar Spain» (Morcillo, 2010: 19). With the onset of the war, the Nazis regulated it too: they even established brothel barracks in concentration camps «to increase the efficiency of production by granting selected [male] prisoners the right to frequent a brothel» (Sommer, 2008: 169).

9 Thus, the feminist motto «My body my choice» used to fight for reproductive rights has been co-opted by proprostitution campaigners to claim women have the «right» to prostitute themselves.
} 
Terry Eagleton wrote in The Illusions of Postmodernism (1996) that members of the Left masked their loss as a triumph when global capitalism completed its hegemony after the fall of communism. Questioning injustices can be overwhelming, therefore reinterpreting them becomes tempting (Ekman, 2013: 82). Since speaking up against the violence that women endure within prostitution does not eliminate it, acknowledging it can be damaging from a personal and psychological point of view. Nowadays, in what appears to be an example of such psychological process, many prostitution defenders claim prostitution is a «sexual liberation» of sorts or, as Salazar (2017: 162) points out, just another way for poor women to make money and survive, presenting it like an acceptable, even desirable option - for women. ${ }^{10}$

Neoliberal capitalism has become normalised to the extent of fully accepting that, since the reduction of the individual to a commodity cannot be avoided, it does not matter the way in which s/he is exploited. This model thrives for alienated individuals that «freely decide» to put themselves at service of the interests of the market. Conceiving body and soul/self as separate entities ${ }^{11}$ is a useful strategy for the capitalist system for it makes possible to argue that a person «is free to do the selling, while the body is sold» (Ekman, 2013: 89). Not questioning neoliberal power relations is, ultimately, conformist. When this logic is applied to prostitution, patriarchal power relations are completely invisibilised. A feminist analysis of prostitution must go beyond neoliberal logics and address that prostitution is unique due to the dynamic between sexuality, the body and the sense of self (Pateman, 1988) and that it «should not be reframed as employment like any other since it is ontologically damaging to the embodied self ${ }^{12}$ (Coy, 2009: 66). Certainly, in a context that affects gender power relations so deeply as does that of prostitution, focusing on the supposedly «free choice» of women to enter prostitution becomes a strategy not to question men who, most definitely, freely choose to demand prostitution.

\subsection{Violence}

In addition to all this, sex buyers' attitudes toward prostitutes need further scholarly attention, as these men are likely to hold beliefs linked to the perpetration of violence against women (Monto, 2004: 184). Indeed, studies show that women and transgender people are more likely than $\operatorname{men}^{13}$ to experience physical assault and rape

10 It is never defended as «a sexual liberation for men», or as «a way for poor men to make money». This alone should suffice to prove the hypocritical double-standard of such argument.

11 For the role of dualism, present throughout Western philosophy from Plato to Descartes, in neoliberal defences of prostitution see Ekman (2013).

12 Her participants' narratives showed that their entry into prostitution was embedded in previous experiences of objectification and sexual abuse. Early sexualisation convinced them that male abusers, supported by socio-cultural norms, «have the right to define meanings attached to women's bodies where women are valued primarily for their sexualized bodies» and that «sexual abuse signifies to women that bodies can be appropriated by others for their sexual gratification, reinforcing both a sense of personal powerlessness, and (dis)embodiment, and wider male entitlement of sexual access to women» (Coy, 2009: 66).

13 In Australia and Argentina, 3.9\% and 1.7\% of male prostitutes, respectively, reported violence (Scott et al. 2005, 20). Farley's findings (2008b) indicated that, across nine countries, $60 \%-75 \%$ prostituted women had been raped, $68 \%$ met 
in prostitution. To be female - or perceived as female- implies to be more intensely targeted for violence (Farley \& Barkan, 2008a: 41). Therefore, gender does qualitatively affect the experience of prostituted people and to regard it as if it were «gender neutral» is deceiving. ${ }^{14}$

\section{METHODOLOGY}

This study of sex buyers' discourse was carried out by means of Critical Discourse Analysis (CDA), which provided the means to approach the issue in a systematic, critical way because it focuses on the relationship between discourse and power relations. ${ }^{15}$ According to Teun van Dijk, CDA has to theoretically bridge the «gap» between the microlevel -all the subtle ways through which power relations get enacted at a smaller scale- and the macrolevel - power, dominance, and inequality between social groups - and make explicit the connection between them (2015: 468). The perspective of CDA should be that of those who suffer most from dominance and inequality, as van Dijk defends, and the critical targets should be the (in this case, patriarchal) power elites that enact, legitimate, or condone social inequality and injustice.

\subsection{Field-work procedure}

For this analysis, six websites belonging to the European English-speaking territory were considered, all of them advertising female «escort services» in the United Kingdom and the Republic of Ireland: www.IrishIndependentEscorts.com, www.Escort-Ireland.com, www.AdultWork.com, www.Backpage.co.uk, www.UKpunting.com and www.PunterNet.com. After some initial consideration, the focus was put entirely on www.PunterNet.com, which was created in 1999 and presents itself as «The UK's oldest escort directory and review site». The other ones were discarded using criteria based on popularity among users. ${ }^{16}$

The amount of reviews provided by PunterNet alone was large enough to offer an overwhelmingly wide sample, and data collected from it seemed to suffice for this type of qualitative analysis. Also, PunterNet is relevant not only as one of the most popular webs among English-speaking sex buyers in Europe, but for having been openly accused of being a website «where pimps put women on sale for sex and then men who've had sex with them put their comments online», thus fuelling «the de-

criteria for Post-Traumatic Stress Disorder in the same range as treatment-seeking combat veterans and refugees from state-organised torture. In Canada, prostituted women's death rate was found to be 40 times higher than the general population's (Special Committee on Pornography and Prostitution, 1985).

14 Some studies focus on male prostitution as part of an analysis of the taboo surrounding (male) homosexual identity (Scott et al., 2005).

15 The origins of CDA can be traced in the work of linguists such as Ferdinand de Saussure (1857-1913), «father of modern linguistics», who wrote on the relation between language and society. The Frankfurt School was also greatly influential. The work of Michel Foucault (1926-1984) was particularly relevant for the analysis of power relations and the production of knowledge through discourse, and therefore for CDA.

16 See Senent (2017) for more on this. 
mand for prostitutes» and putting «women at risk». ${ }^{7}$ It is worth noting, though, that this kind of virtual communities can be found in every country. In Spain, for instance, a very popular one is the Foro-Putas section of www.Putalocura.com, which Beatriz Ranea has used to highlight the importance of critically addressing the social impact of sex buyers' opinions on women and girls - migrants in their great majority- prostituted in Spain (Ranea, 2017: 140-141).

\section{SEX BUYERS' DISCOURSE}

The reviews are guides for sex buyers to decide which woman/girl to choose. After considering an approximate number of 200 reviews, 6o were selected as a manageable sample and analysed. Thirty were labelled as «positive» and thirty as «negative» («Recommended», «Not recommended»). They were examined as instances of sexual politics in the sense developed by Kate Millett in Sexual Politics, using CDA to reveal the symbolic power structure of sex buyers' discourse. On the website's language, the women are called «service providers». This terminology is key to the ideology of the proprostitution lobby that aims at legitimating the commodification of women's bodies as a product. The terminology of pro-sex work feminists is absent though: neither «sex worker» nor «sex work» is used, which also reveals the website's anti-feminist stand.

Sex buyers generally describe women mentioning body parts along with one or several adjectives. Comments that declare women to be «good value for money» (and the opposed: «waste of money/time») are common. Objectifying language is overtly used, a form of symbolic violence per se. ${ }^{18}$ Certain data provided about women, such as being stressed out, may result in suspicion as to whether she may have been forced into prostitution - especially if a pimp is involved-but the men do not dwell on these. The analysis of the selected reviews proves that the community values young prostitutes, ${ }^{19}$ as the men frequently insist on their youth. A lack of fluency in English is often mentioned as something that improves or worsens the level of the «service» depending on their expectations. Some complain because the lack of English makes things «impersonal», others do not care because they are not there to talk.

The same qualities that are sought by sex buyers «are known to be risk factors for sex trafficking, for example, young age, low price, foreigner or "exotic", and inability to speak the local language» (Farley et al., 2011b: 3). The high demand for young girls in prostitution on the part of adult men puts runaway and unskilled girls in danger of

17 Harriet Harman tells Arnold Schwarzenegger to shut down website which tells punters to rate prostitutes (30 September, 2009) Dailymail.co.uk. Retrieved from http://www.dailymail.co.uk/news/article-1217222/Website-allowspunters-rate-prostitutes-performance-closed-says-Harriet-Harman.html\#ixzz4hNCwC5WZ [Consulted $13^{\text {th }}$ September, 2018]. Despite these accusations, the website is under the protection of the United States Constitution and its guaranteed right of free speech as its domain is in California.

18 Women are often compared and/or equated with objects and lifeless matter. It is common to comment on the quality of their vaginas and reduce the value of the prostitute and her «service» to that (see pages 14-15 for concrete examples).

19 Rachel Moran used to tell them that she was 15 because «it had the almost universal effect of causing them to become very aroused and to climax easily», which was convenient because the experience would be «over with quickly» (2013: 61). 
being pulled into prostitution at an early age if they find themselves in difficult circumstances (Walter, 2010: 57). Importantly, not speaking the local language increases women's social vulnerability and the chances for them to be exploited by pimps, agencies and/or sex buyers.

Sex buyers endorse acts of symbolic solidarity that reinforce the dichotomous division between «us» (men/sex buyers) and «them» (women/prostitutes) upon which the community is constructed. In this online context, such acts include the very act of recommending positively/negatively, but also an attitude of camaraderie typical of male peer groups, which have been said to be a potential broth for the kind of masculine attitudes that are likely to perpetrate and endorse violence against women (Connell, 1995). Their one-sided discourse is not only a manifestation of the structural inequality inherent in prostitution, but a discursive strategy that symbolically reveals a main characteristic of patriarchal masculinities: «male complicity in women' social discrimination» (Sambade, 2017: 175). Solidarity towards prostitutes, particularly towards a prostitute who did not provide the so-called «good service», is unthinkable.

For example, the analysis of the review by «EJ82» shows his utter lack of respect and empathy, with comments like «She gets pissed and says, 'I am not a sex machine! I am a woman! Respect me!' What the fuck? I just stair [sic ${ }^{20}$ at her blankly, what is she talking about?» and «So we do doggy and I like that because she has a nice ass and I don't have to see her stupid face». To pay teenagers for sex seems not problematic for «oldbutstillovingit», who was 70 while the reviewed prostituted girl was allegedly 18 : he portrayed himself as a «customer» whose «needs» were not met because she showed signs of being uncomfortable, «in a hurry to get it over with», the «hand job was dire» and «kissing wasn't good». As Natasha Walter has noted, if we read the men's words in PunterNet «from the point of view of the women, whose reluctance, pain and unhappiness» is often clear, «the effect is traumatic» (2010: 57 ).

\subsection{Positive reviews}

\subsubsection{Good service: «she didn't complain» ${ }^{21}$}

Through the positive reviews, sex buyers advice each other about purchasing certain women that gave the so-called «good service», which is defined by her being «accommodating», «solicitous», and allow him to do whatever he wants. Sex buyers are not interested in the women's reasons to set limits, so they tend not to register them in their reviews. They stress when women do not set limits because they value that positively. The aim of the encounter is to satisfy men's sexual and ego-related expectations. Thus, expressions such as «made an effort to handle it», «never asks you to stop», and «she didn't complain» are common and highlighted as positive.

Sex buyers' grammatical mistakes as found in the original reviews were transcribed as such.

21 «I hadn't cum for 36 hours and so it was quite a violent spurt, but, game girl that she is, she didn't complain» (MrHenryWillis). 


\subsection{2 «True whore»: the ideal prostitute}

The verbs in active (for men) and passive form (for women) reveal a belief system that holds sex to be a male terrain. The use of the passive way - « [she] gets fucked [repeatedly]», «she [has] been fucked by over 250 men»- proves that they do not recognise prostitutes as sexually liberated «sex workers» but as sex objects that «get fucked». They use the word «whore» to stigmatise female sexual activity in general and (re-) produce the «whore stigma» denounced by sex-work feminists, thus reinforcing the double standard - even in a prostitute-prostitutor relationship, so they are likely to hold the same belief system when judging non-prostituted women who have sex for the sake of it.

\subsubsection{Female (lack of) pleasure}

Research conducted on sex buyers across different countries show most of them believe prostituted women and girls enjoy the sex (Farley, 2011a; Barahona \& García, 2003). Many ex-prostituted women have spoken about their feelings of degradation and self-hatred due to sex buyers' disrespectful behaviour, their shivering panic when they meet a new «client». While keeping boundaries is a basic survival strategy for women in prostitution, the men are often offended when their efforts become evident. Autumn Burris, founder of Survivors for Solutions, wrote: «I coped with all the unwanted sexual exchanges by limiting the amount of time with each sex buyer and instituting non-verbal and/or verbal boundaries» (2016: 136). «Mademoiselle» has written:

If I enjoyed having sex with disgusting, dirty strangers why would I charge them money for it? [...] I found it incredibly stressful. Whenever I heard the buzzer announcing a new client I would jump. I found it so degrading to have the men decide which girl to pick. I never got used to it and found it humiliating (2016: 130-133).

Tanja Rahm ${ }^{22}$ stated that all sex buyers are men «who find their needs more important than the safety of women», who «let go of all respect and empathy, when they buy access to women's bodies» and «feel this [anonymity] gives them the right to show as little respect as possible. They feel entitled to belittle and humiliate women they have paid to satisfy their sexual needs». ${ }^{23}$ The review system in PunterNet is structured in a way that perpetuates such a gap, thus protecting the lies men choose to believe -lies that are at the base of prostitution itself.

22 This Danish therapist and anti-prostitution campaigner wrote «A letter to my Johns» (2016: 79-90), a powerful open letter where she speaks about her negative feelings during her encounters with sex buyers.

23 Rahm, Tanja (2014). My speech at the feminism conference in London. Retrieved from http://tanjarahm.dk/44-myspeech-at-the-feminism-conference-in-london/ [Consulted 30 $0^{\text {th }}$ August, 2018]. 


\subsection{Negative reviews}

\subsubsection{Bad service: «counted her money twice» ${ }^{24}$}

Through the reviews labelled as negative, sex buyers construct what a «bad service» is, which is defined by being keen on money, having sex in a «unenthusiastic», «dispassionate» manner, showing «complete indifference» and/or not being able to pretend the man is smart and funny by laughing at his jokes. If she fails to provide him with such «services», sex buyers decide that they are «not cut out» for being prostitutes. The lexical choices characteristic of the negative reviews aim at portraying themselves as the affronted party, and omit details that may explain women's behaviour. Often, prostitutors feel cheated when they do not get a "good service». When sex is regarded as a service, the best «bargain» is highly valued. But the very terminology used to mask what is behind the prostitution contract is treacherous.

As customers that pay for a service, they should expect the other party to be mainly keen on money. Despite wrapping the prostitution gendered relation with neoliberal, business-related terms aimed at justifying the buying of sex, they do not want prostitutes to have the professional behaviour of money-driven business-women. This reveals an inner fundamental contradiction in their attitude towards prostitution as «a job». Money is the only reason for which an individual would «sell services», and girls and women in prostitution would not have sex with sex buyers if they were not being paid for it. That is why men must pay them. And that is what creates immense tension in feminist debates: the fact that a woman must renounce her own sexual desire for a man to satisfy his - something inherent in the prostitution contract (Pateman, 1988). Ultimately, the demand for money in the transaction is crucial, as it shows «that a woman's sexual compliance in the acts were otherwise unwanted» (Baldwin, 1992: 119).

\subsubsection{Boundaries and dissociation}

Certain things sex buyers complain about ${ }^{25}$ are highlighted in prostitution research as women's survival mechanisms. A major survival strategy consists on the need of dissociating (split between «personal self»/«prostituted self») making use of tactics like the setting up of physical and emotional boundaries. Maddy Coy defines dissociation from the body as «leaving it emotionally when it is impossible to leave physically» and points out this psychological defence strategy is a well-documented reaction to trauma - particularly sexual abuse. The women she interviewed dissociated as a coping mechanism during commercial sex exchanges: they linked surviving sexual abuse in childhood with «switching off» from the body and repeated it in prostitution.

This «unplugging technique», consisting on split into two characters, «the authentic me and the imaginary version» (Moran, 2013: 137, 143) enables women «to remain calm throughout each commercial sex encounter» until it becomes an automatic re-

24 «Greeted by common as fuck gum chewing hungaryan whore. counted her money twice, thats all that matters» (onewhodid).

$25 \ll$ [20 minutes later] I'd had enough. She seemed surprised but considering she hardly spoke, made no noises (even fake ones) and had all the enthusiasm of a corpse, she shouldn't have been» (Puntderby). 
sponse (Coy, 2009: 68-69). Unlike the worker who tries to fight against alienation and separation from the product of her/his labour, alienation and separation for prostituted women is essential for survival. In that sense, «prostitution is the epitomisation of alienation» (Edwards, 1996: 99).

\subsubsection{Basic services}

The prostitutors within the PunterNet community have developed the notion of basic services which implies certain sexual practices can be taken for granted. Ideally, everything should be «on sale». Otherwise, some «services» should be guaranteed. This goes against dissociation and boundaries, the crucial survival strategies mentioned above. Calling practices that women reject to perform «basic services» trivialises their right to set up physical and emotional boundaries with whoever they do not want to intimate. Also, our evidence shows that the sexual preferences of sex buyers include practices that may lead to pregnancy and/or venereal diseases (oral, anal, vaginal sex without condom, for which they are often willing to pay more ${ }^{26}$ ) and porn-like sex that may cause bleeding, bruises, cervical injuries, etc. In this sense, their notion of «basic services» is both a potential form of violence and a public health issue.

\section{INCOMPATIBILITY OF SEX BUYERS DEMAND FOR PROSTITUTION WITH FEMINIST PRINCIPLES}

There are two core pieces to prostitution: one party wants sex, the other does not. The former has money, the latter needs money. The economic power enacted in the act of buying sex cannot be ignored. The payment of money symbolically and effectively excludes female sexual pleasure (and women's conditions in general ${ }^{27}$ ) from the prostitution contract. Proponents of the legalisation and decriminalisation model promote the idealistic notion that women are free to choose «clients» and set up limits. They should be concerned with sex buyers' expectations. Our data indicates that when sex buyers face boundaries, they can write a negative review online and look for a different «service provider» next time: one who is more «accommodating» or cannot say no. To be able «to keep the job» potentially entails allowing sex buyers to violate personal boundaries, when not having to deal with them imposing their conditions by force.

Sex buyers' lexical choices prove they do not intend to establish a commercial type of relationship based on equality and mutual respect. Women are systematically objectified and often treated with contempt in positive ${ }^{28}$ and negative reviews. ${ }^{29}$ Their feel-

26 Oral sex without condom is sometimes treated as «basic service» and using condom as «not erotic». In some privileged circumstances, prostituted women may be able to negotiate this. The least privileged may not.

27 This does not deny women's individual ability to resist that, but the fact that they may need «to resist» proves the logics of prostitution are not on their side.

28 «Nice pussy not a complete bucket like some escorts! [...] fucked her from behind with her amazing arse there for me to look at when i came. i pulled out of her pussy slipped the jonny [condom] off and covered her [with semen]. Again she was nice and didn't run off like many escorts» (mikeyfin). 
ings of entitlement to a female subservient attitude ${ }^{30}$ are likely to be dangerous for all women. Signs of possible trafficking are either disregarded as irrelevant ${ }^{31}$ or ignored when presented. ${ }^{2}$ This is consistent with previous research that found the suspicion of trafficking and the awareness of prostitution negatively affecting women's lives are not considered as a deterrent for buying sex (Farley et al., 2011a; Barahona \& García, 2003) and proves they do not care about women's supposedly «free choice» to enter prostitution. ${ }^{33}$ A prostitute accepts money before each experience, and nothing guarantees that prostitutors will respect her boundaries (Moran, 2013: 112). Therefore, the money factor blurs the meaning of the «no is no» feminist mantra aiming at making men respect women's sexual freedom and boundaries in any context besides and beyond prostitution.

The «unfortunate» encounters narrated in the negative reviews prove sexual relations that take place in prostitution to be the wrap for male expectations of dominance. Anger and resentment arise when such expectations are not met. In all cases, they point at the women as the ones held accountable for working as prostitutes, without taking responsibility for their role as sex buyers - even in cases where control by pimps was evident. The self-complacent language characteristic of the positive reviews $^{34}$ turns into an overtly violent language in the negative ones, ${ }^{35}$ indicating traits of a hostile type of masculinity which reveals misogynistic attitudes that come close to violence against women. Prostitution dehumanises women, not because they «dehumanise themselves» by being involved in prostitution, but because of the sex buyers' tendency to objectify and dehumanise them. The potentially dangerous consequences this may have on men's actual behaviour with them cannot be regarded as irrelevant.

Trying to make prostitution look like a matter of «moralism» seems rather frivolous when feminists should be worrying about women's actual working conditions. Not only it is not easy to identify what the skills inherent in the «job» ${ }^{36}$ would be, but they are likely to be based on irreconcilable notions for sex buyers and for prostituted women. Rachel Moran has reduced to three the necessary «skills set», which are very far

29 «Only plus side -reasonably tight pussy- but then,so's the one on my blowup doll -which is possibly more affectionate»(Sirspunkalot).

30 «[Lucy] said "cum on you finish now" WTF“NO, I paid to have sex with you" Still fully clothed![...] pushed me back on the bed, grabbed my cock and despite me saying "NO, I WANT SEX" about 5 times, she had spunked me all over the place with her hands in about 30 seconds» (volvic).

31 «[Sisi]got narky and told me I owed her and extra tenner now for what I had done[...].[Left] before her PIMP turned up with a baseball bat or something. Saw no evidence of either, but you know what I mean!» (volvic).

$32 \ll$ [Olivia is] not prettier than your average pimped $£ 100$ Polish or Romanian girl [...].I am more inclined towards the premises pimp explanation and him being part of a more organised infrastructure. The certain thing is that he is a [British] pimp and the timekeeper of all the girls working there» (Einrot).

33 «[Olivia] was crying! WTF? [...] her cervix got bruised and she couldn't take any more penetration. [...] If she can't take some hard penetration for $15 \mathrm{mins}$ then she is not cut out to do this job» (Einrot).

34 «Very solicitous. [...] will fulfil all your requests and desires» (gussetmuncher).

35 «I fucked her as hard as I could in doggy,got a few yelps out of her.but she was well used to it.even though shes only a few days in london. Tried to tell me she was some sort of student 'mother of fuck'» (onewhodid); $\ll^{* * *}$ THE WORST RIPOFF MONEY GRABBING WHORE OF A ROMANIAN WG [working girl] I HAVE EVER ENCOUNTERED ${ }^{* *}[. .$.$] SHE DID NOT EVEN TAKE ANY OF HER CLOTHES OFF OR LET ME$ TOUCH HER TITS OR CUNT.avoid**avoid"*avoid**avoid» (Volvic).

36 See WHISPER's satirical CV «to apply» for prostitution in Senent (2017), Appendix B. 
from what entails «being professional» for sex buyers: «The ability to control your reflex to vomit. The ability to restrain your urge to cry. The ability to imagine your current reality is not happening» (2013: 225). Thus, the business-related terminology used by pro-prostitution campaigners is an imperfect way of masking the abuse women must endure within prostitution.

The concept of «basic services» adds up to the issue of prostitution as a job: what practices should be part of the job? Could the government, prostituted women and sex buyers agree? Is it morally legitimate that a woman's physical and mental health must be put at risk to "provide a service» men require? Since prostitution involves sex, can the government legitimately regulate the sexual lives of individuals? Of which individuals, under what principles, and to what extent? As a potentially dangerous job, workers' health should be protected by the government, but how can women's health be protected from their customers' requirements under a policy of legalisation or decriminalisation which obviously disregards the questionable hidden aspects of buying sex by treating it as a legitimate practice? For prostitution to be less dangerous and damaging for women, men's requirements should change, something that falls far from the scope of legalisation and decriminalisation.

\section{CONCLUSIONS}

The gendered character of prostitution, based on socially and economically nonegalitarian conditions and on the male sex-right to ensure men's access to women's bodies, exemplifies the enactment of patriarchal power relations in a particularly clear way (Pateman, 1988). By writing public reviews of prostituted women and girls in virtual communities such as PunterNet, men control the context for the production of a type of discourse that determines the «ideal» terms and conditions under which they want the prostitution contract to take place, thus contributing to «the normalisation of the prostitutor's agency» (Sambade, 2017: 17o). According to a Foucaultian notion of power as productive and relational, enacted through discourse, we can say that individual men are producers of the patriarchal discourse of power, active participants in its application and the embodied vehicle of its practical, innumerable manifestations, which contribute to legitimate gender-based inequality.

Face-to-face interactions within prostitution would need to be equality-based for women not to suffer male violence under a policy of decriminalisation or legalisation. However, as we have seen, sex buyers' recounts indicate they regard the objectification and dehumanisation of women as inherent in prostitution. Thus, there is evidence from the buyers themselves supporting the claims made by anti-prostitution researchers and survivors according to which it is a degrading and violent practice. Their construction of an ideal type of heterosexual liaisons based on the notion of «good service», in which female (real) sexual desire is not rendered necessary for sex to take place, is likely to feed their feelings of entitlement to non-consensual sex. Ultimately, legally legitimising the enactment of men's economic power to buy a fantasy of masculine sexual potency 
based on non-egalitarian conditions implicitly supports and perpetuates violence against women at a larger scale.

Huge economic interests are behind the neoliberal, business-like, discourse of most of those who defend prostitution is a job like any other, such as sex traffickers, pimps and brothel owners - who have the best position under legalisation and decriminalisation policies which allow them to run «the trade openly in cahoots with the state» (Bhattacharya, 2016: 90). Despite a deliberate, strategical co-optation of feminist terms, the aims and interests of the pro-prostitution lobby are intrinsically anti-feminist. On top of this, prostitution is not «some magical arena of life where men decide to treat women as economic equals» (Moran, 2013: 204). On the contrary: its roots are firmly entrenched in socially and economically non-egalitarian, gendered conditions and, as our analysis revealed, it tells men they can buy a self-coerced, subservient role of women and potentially enact traditional gender roles without being effectively challenged.

Prostitution damages all women by providing a locus for the enactment of a type of masculinity with overt misogynistic bias, where male ego and his sexual fulfilment are central and where money buys the right to disregard women's sexual desire, health, and well-being. Sex buyers' interests go directly against feminist principles, so defending their interests with feminist arguments is not possible without falling into contradictions. In the light of all this, feminists should counterattack the ability of patriarchal capitalism to phagocytise the revolutionary potential of the movement by uniting themselves in questioning the legitimacy of neoliberal discourses while holding men accountable for the perpetuation of prostitution, and request from governments a legal, gender-sensitive approach that tackles the demand and truly commits to fight violence against women in its many forms.

\section{BIBLIOGRAPHY}

Barahona, María José \& García, Luis Mariano (2003). Una aproximación al perfil del cliente de prostitución femenina en la Comunidad de Madrid. Madrid: Publicaciones DGM.

Barry, Kathleen (1979). Female sexual slavery. New Jersey: Prentice-Hall.

Bhattacharya, Malini (2016). Neither 'Free' nor 'Equal' Work: A MarxistFeminist Perspective on Prostitution. ANTYAJAA: Indian Journal of Women and Social Change, 1(1), 82-92.

Burris, Autumn (2016). No Life for a Human Being. In Norma, Caroline \& Tankard Reist, Melinda (Eds.). Prostitution Narratives (136-140). Victoria: Spinifex Press.

Carter, Vednita \& Giobbe, Evelina (2006). Duet. In Spector, Jessica (Ed.). Prostitution and Pornography. Philosophical Debate about the Sex Industry (1739). Standford: Standford University Press. 
Cho, Seo-Young; Dreher, Axel \& Neumayer, Eric (2013). Does Legalized Prostitution Increase Human Trafficking? World Development, 41, 67-82.

Cobo, Rosa (2017). La prostitución en el corazón del capitalismo. Madrid: Catarata.

Connell, Raewyn W. (1995). Masculinities. Cambridge: Polity Press.

Coy, Maddy (2009). This body which is not mine. The notion of the habit body, prostitution and (dis)embodiment. Feminist Theory, 10(1), 61-75.

De Marneffe, Peter (2010). Liberalism and prostitution. Oxford: Oxford University Press.

De Miguel, Ana (2015). Neoliberalismo sexual: el mito de la libre elección. Madrid: Ediciones Cátedra.

Edwards, Susan (1996). Selling the Body, Keeping the Soul: Sexuality, Power, the Theories and Realities of Prostitution. In Scott, Sue \& Morgan, David (Eds.). Body Matters: Essays on the Sociology of the Body (89-104). London: The Falmer Press.

Ekman, Kajsa Ekis (2013). Being and being bought: Prostitution, Surrogacy and the Split Self. Victoria: Spinifex Press.

Farley, Melissa \& Barkan, Howard (2008a). Prostitution, Violence, and Posttraumatic Stress Disorder. Women \& Health, 27(3), 37-49.

Farley, Melissa; Cotton, Ann; Lynne, Jacqueline; Zumbeck, Sybille; Spiwak, Frida; Reyes, Maria; Alvarez, Dinorah \& Sezgin, Ufuk (20o8b). Prostitution and Trafficking in Nine Countries. Journal of Trauma Practice, 2(3-4), 33-74.

Farley, Melissa; Golding, Jacqueline; Schuckman-Matthews, Emily; Malamuth, Neil \& Jarrett, Laura (2011a). Comparing Sex Buyers with Men Who Don't Buy Sex. Psychologists for Social Responsibility Annual Meeting in Boston. San Francisco: Prostitution Research \& Education.

Farley, Melissa; Macleod, Jan; Anderson, Lynn \& Golding, Jacqueline (2011b). Attitudes and social characteristics of men who buy sex in Scotland. Psychological Trauma: Theory, Research, Practice, and Policy, 3(4), 369-383. doi: $10.1037 /$ aoo22645.

Gimeno, Beatriz (2018). La nueva utilidad de la prostitución en el neoliberalismo. Atlántidas. Revista Internacional de Estudios Feministas, 3(1), 13-32.

Harriet Harman tells Arnold Schwarzenegger to shut down website which tells punters to rate prostitutes (zo September, 2009) Dailymail.co.uk. Retrieved from http://www.dailymail.co.uk/news/article-1217222/Website- 
allows-punters-rate-prostitutes-performance-closed-says-HarrietHarman.html\#ixzz4hNCwC5 WZ. [Consulted $13^{\text {th }}$ September, 2018]. Jeffreys, Sheila (2008). The idea of prostitution. Melbourne: Spinifex Press. Kemp, Tage (1936). Prostitution; an investigation of its causes, especially with regard to hereditary factors. Copenhagen: Levin \& Munksgaard.

Kollontă1, Aleksandra (1977). Selected writings of Aleksandra Kollontăl. Canada: Allison \& Busby.

Lenin, Vladimir Ilyich (1971). Collected Works. Moscow: Progress Publishers. «Mademoiselle» (2016). Goodbye Mademoiselle. In Norma, Caroline \& Tankard Reist, Melinda (Eds). Prostitution Narratives (112-135). Victoria: Spinifex Press.

Monto, Martin (2004). Female Prostitution, Customers, and Violence. Violence Against Women, 10(2), 160-188.

Moran, Rachel (2013). Paid for. My Journey Through Prostitution. Dublin: Gill \& Macmillan.

Morcillo, Aurora (2010). The Seduction of Modern Spain: The Female Body and the Francoist Body Politic. Lewisburg: Bucknell.

O'Connell Davidson, Julia (2002). The Rights and Wrongs of Prostitution. Hypatia, $17(2), 84-98$.

Pateman, Carole (1988). The Sexual Contract. Standford: Standford University Press.

Prostitution Revenue by Country. Global Black-Market Information. Havocscope. Retrieved from http://www.havocscope.com/prostitutionrevenue-by-country/. [Consulted $26^{\text {th }}$ August, 2018].

PunterNet. Retrieved from http://www.punternet.com/index.php. [Consulted $13^{\text {th }}$ November, 2018].

Rahm, Tanja (2016). Internalising the Violence. In Norma, Caroline \& Tankard Reist, Melinda (Eds.). Prostitution Narratives (79-90). Victoria: Spinifex Press.

Rahm, Tanja (2014). My speech at the feminism conference in London. Retrieved from http://tanjarahm.dk/44-my-speech-at-the-feminismconference-in-london/. [Consulted 20 ${ }^{\text {th }}$ August, 2018].

Ranea, Beatriz (2017). (Re)pensar la prostitución desde el análisis crítico de la masculinidad. In Nuño, Laura \& de Miguel, Ana (Eds.). Elementos para una teoría crítica del sistema prostitucional (135-142). Granada: Comares.

Raymond, Janice (2003). Ten Reasons for Not Legalizing Prostitution and a Legal Response to the Demand for Prostitution. Journal of Trauma Practice, $2,315-33^{2}$. 
Salazar, Octavio (2012). Otras masculinidades posibles: Hacia una humanidad diferente y diferenciada. Recerca, 12(6), 87-112.

Salazar, Octavio (2017). Prostitución y desigualdad: la necesaria deslegitimación de los sujetos prostituyentes. In Nuño, Laura \& de Miguel, Ana (Eds). Elementos para una teoría crítica del sistema prostitucional (157-168). Granada: Comares.

Sambade, Iván (2017). La instrumentalización de la sexualidad. Masculinidad patriarcal, pornografía y prostitución. In Nuño, Laura \& de Miguel, Ana (Eds.). Elementos para una teoría crítica del sistema prostitucional (169-180). Granada: Comares.

Scott, John; Minichiello, Victor; Marino, Rodrigo; Harvey, Glenn \& Jamieson, Maggie (2005). Understanding the new context of the male sex work industry. Journal of Interpersonal Violence, 20(3), 320-342.

Senent, Rosa M. (2017). He who pays the piper calls the tune: masculinity and sex purchase online - a critical discourse analysis. MA Thesis. Oviedo/Poland: University of Oviedo/University of Łódź.

Sommer, Robert (2008). Camp Brothels: Forced Sex Labour in Nazi Concentration Camps. Brutality and Desire: War and Sexuality in Europe's Twentieth Century (168-196). United Kingdom: Palgrave Macmillan.

van Dijk, Teun (2015). Critical Discourse Analysis. In Tannen, Deborah; Schiffrin, Deborah \& Hamilton, Heidi (Ed.). The Handbook of Discourse Analysis (352-371). Hoboken: Wiley-Blackwell.

Walter, Natasha (2010). Living Dolls. The Return of Sexism. London: Virago. 
128 RECERCA · DOI: http://dx.doi.org/10.6035/Recerca.2019.24.2.6 · ISSN: 1130-6149-pp. 109-128 